\title{
Going in the udder direction: Trophic spacing, mobility and weaning assessed through stable $\mathrm{Ca}$ and $\mathrm{Sr}$ isotopes in cattle
}

\author{
JAMIE LEWIS ${ }^{1}$, TU-HAN LUU ${ }^{2}$, DANIEL BEVAN ${ }^{1}$, IAIN P. \\ KENDALL ${ }^{1}$, MICHAEL R.F. LEE ${ }^{1,3,4}$, RICHARD P. \\ EVERSHED $^{1}$ AND TIM ELLIOTT ${ }^{1}$ \\ ${ }^{1}$ University of Bristol \\ ${ }^{2}$ Université de Paris - IPGP - CNRS/UMR 7154 \\ ${ }^{3}$ Harper Adams University \\ ${ }^{4}$ North Wyke, Rothamsted Research \\ Presenting Author: jamie.lewis@bristol.ac.uk
}

In the past decades, isotopic information has revolutionised our ability to understand and interpret the lifeways, subsistence practices and animal husbandry practices of past populations. The use of mass dependent and mass independent fractionation in metal isotopes has played an important part of this. In applying these isotopic techniques to past human and animal populations, it has become apparent that our fundamental understanding of the isotopic systematics we employ is as important as our application of them to past populations. Whilst our understanding of the isotopic systematics has grown and broadly matured alongside the discipline, our knowledge is most effectively grounded and tested through modern natural experiments under controlled conditions.

We present the results of such a study. We have analysed soils, plants, and sequentially sampled cattle enamel from the North Wyke Farm Platform (Rothamsted Research), for stable calcium isotopes $\left(\delta^{44 / 40} \mathrm{Ca}\right)$, and for radiogenic $\left({ }^{87} \mathrm{Sr} /{ }^{86} \mathrm{Sr}\right)$ and stable $\left(\delta^{88 / 86} \mathrm{Sr}\right)$ strontium isotopes. Calcium isotopes have been measured using a novel collision cell MC-ICPMS (Thermo Scientific Proteus) using helium and hydrogen reaction gases to charge neutralise the intense ${ }^{40} \mathrm{Ar}^{+}$beam and directly measure the ${ }^{40} \mathrm{Ca}$ isotope. Strontium isotopes have been measured by TIMS (Thermo Scientific Triton). Both $\delta^{44 / 40} \mathrm{Ca}$ and $\delta^{88 / 86} \mathrm{Sr}$ measurements have been made using the double spike technique using ${ }^{42} \mathrm{Ca}-{ }^{43} \mathrm{Ca}$ and ${ }^{84} \mathrm{Sr}-{ }^{87} \mathrm{Sr}$ double spike, respectively.

Our results show trophic level fractionations in both isotope systems. The magnitude of the fractionation in $\delta^{44 / 40} \mathrm{Ca}$ is in agreement with previously reported data $\left(\Delta^{44 / 40} \mathrm{Ca}_{\text {Enamel-Plant }} \sim 1.1\right.$ $\%$ ) whilst the fractionation in $\delta^{88 / 86} \mathrm{Sr}$ is slightly larger than that reported in previous trophic studies in animals with $\Delta^{88 / 86} \mathrm{Sr}_{\text {Enamel- }}$ Plant $\sim 0.46 \%$. Our results also have implications for the way single event migrations are recorded in sequential enamel samples, recording the movement of the steers and heifers on to the Farm Platform following weaning from their mothers. Finally, our results show the effect of weaning and change of pasture type on metal stable isotopes in sequentially sampled enamel. 